\title{
Mediation Effect of Knowledge Sharing Quality on Employee Creativity
}

\author{
Dimitry Doronin ${ }^{1}$, Shen Lei $^{2}, \&$ Shan SYED HAMAD HASSAN ${ }^{1}$ \\ ${ }^{1} \mathrm{PhD}$ candidate at Donghua University, China \\ ${ }^{2}$ Shen Lei, Professor at Business School of Donghua University, Shanghai, China \\ Correspondence: Dimitry Doronin, Donghua University, China.
}

Received: December 20, 2021

Accepted: January 26, 2022

Online Published: January 30, 2022

doi:10.5539/ibr.v15n2p75

URL: https://doi.org/10.5539/ibr.v15n2p75

\begin{abstract}
Employee creativity requires knowledge sharing, according to many experts. What aspects of the knowledge sharing cycle encourage employee creativity? In this study, authors examined three factors, i.e., 'opportunity for exchange (OFE), value anticipation (VA), and motivation to engage (MTE)', that influence the production of intellectual capital (as antecedents) and its effects on employee creativity (as outcomes) through knowledge sharing (KS) and quality of knowledge sharing (QKS: as mediating mechanism). To test the hypothesized relationships, Mplus was used to analyze 371 Russian IT employees. The findings suggest that OFE, VA and MTE are important antecedents of both KS and QKS. Moreover, KS and QKS mediates the relationship between antecedents (OFE, VA and MTE) and outcome variable (employee creativity). Theoretical contribution and future research are discussed.
\end{abstract}

Keywords: employee creativity, parallel mediation, knowledge sharing, quality of knowledge sharing

\section{Introduction}

Organizations are increasingly reliant on their employees' creativity and innovation to develop products, improve services, and manage operations. According to sholars (e.g., Castaneda \& Cuellar, 2019) innovation is a key organizational capability for gaining and maintaining a competitive advantage. It relies heavily on worker-to-worker knowledge exchange. According to the Ceylan (2003), knowledge contributes to a competitive advantage by improving or designing new products or services. Researchers are looking into ways to motivate employees to share knowledge and experience at work. employees in organizations need to understand the influences and mechanisms that drive them to share their valuable knowledge with others (Razaka et al., 2016). Thus, knowledge management practices are becoming increasingly important in boosting firms' innovation and competitiveness. Firms that actively collect, store, and share knowledge maximize the value of their intangible and tangible assets, as well as their profits and revenues (Ferreira et al, 2018). Studies have shown that knowledge sharing is the main tool for developing intellectual capital (Kianto et al, 2017; Bayraktaroglu et al, 2019).

However, some scholars have expressed concern relating the positive affect of knowledge sharing on firm outcomes. The time spent processing information increases firm performance, according to Haas and Hansen (2007). In a competitive environment, better knowledge management is required to adapt. Changes in knowledge acquisition, creation, and sharing processes require psychological and structural changes (Rusly et al., 2012). As Cornell and Stone (2010) noted, large-scale knowledge sharing (KS) initiatives create pseudo-knowledge. Liu and Phillips (2011) revealed that an organization must ensure that the "right" knowledge is shared.

The purpose of current study is to examine the opportunity for exchange (OFE), value anticipation (VA), and motivation to engage (MTE) as antecedents and employee creativity (EC) as outcomes of KS and QKS. How knowledge sharing affects employee creativity, what quality dimensions of knowledge sharing matter, and what their antecedents are. The academic literature has yet to adequately describe knowledge sharing quality. For instance, Fauzi (2019) conducted a review of 50 articles published between 2006 and 2019 on knowledge sharing in online communities. Four papers make reference to and mention DeLone (Gang and Ravichandran 2014; Shan et al. 2013), five papers make reference to and mention Chiu, Hsu, and Wang (2006) and Hsu, Chang, and Yen (2011), and one paper makes reference to Wasko and Faraj (2005). While modern infrastructure, 
technology, and economic resources all contribute to innovation, knowledge sharing between employees is critical. Product development, according to Cardinal et al. (2001), entails technical, physical, and knowledge components. The innovation process can be conceptualized in three ways: through the employees, their activities, and the modes of innovation (Diercks, Larsen, \& Steward, 2019).

Thus, using intellectual capital constructs as antecedents, this study investigated 'how the quality of KS and QKS' affect employee creativity OFE, VA and MTE. The study's underlying significance is to raise awareness in both business and academia that KS alone is not sufficient to consider in terms of employee and team creativity; rather, the QKS is what truly has a clear impact on an organization's well-being. The study was conducted to insight a better understanding of how KS and QKS affects employee creativity.

\section{Literature review}

\subsection{Relationship Between Antecedent: Knowledge Sharing and Outcome: Employee Creativity}

KS promotes creativity, according to the scholars, innovation and creativity is unlikely without KS (Kremer et al., 2019). Collaboration has proven to be an efficient way of gaining knowledge and skills (Adams et al., 1998). Products and services can be improved or created by exchanging knowledge. Knowing how to share ideas, know-how, and expertise is considered to be a critical factor in employee creativity because sharing ideas, know-how, and expertise increases organizational capital (Cabrera, Al-Kurdi, Nahapiet \& Ghoshal, 1998; Shen et al., 2021b), and integrating individuals' knowledge results in synergy (Nahapiet \& Ghoshal, 1998) Innovation tasks are impossible for a single person to complete in any complex work process; only by assembling an effective team of people with a variety of skills can they be completed (Dong et al., 2017; Zárraga \& Bonache, 2003). Aside from that, the team's ability to think creatively requires them to look at things from a variety of perspectives and combine previously unrelated elements to create something new and improved (Aggarwal et al., 2019). Consequently, the concept of KS has received a great deal of attention from academics.

Researchers who have investigated employee creativity in the past (for example, Ahmad et al., 2019; Park et al., 2018; Muhammad et al., 2017; 2018; Shen et al., 2021a; Subramaniam \& Venkatraman, 2001) have frequently employed knowledge and/or intellectual capital as independent variables, with employee creativity as an outcome variable. "While the invention or conception of innovative ideas may be an individual activity, innovation (the invention and implementation of new ideas) is a collective achievement," Van de Ven (1986) asserted. When it comes to organizations' ability to innovate, their intellectual capital and their ability to leverage their knowledge resources are both important factors to consider. Kane (2017) and others have emphasized that new product development is an expression of organizational knowledge, while others have described employee creativity as a knowledge management process (e.g., Madhavan and Grover, 1998; Yan et al., 2021) or described innovative firms as knowledge-creating organizations (e.g., Madhavan \& Grover, 1998; Nonaka et al, 2018). Muhammad et al. (2017) revealed that, in organization employee talent and knowledge management are critical primary resources in today's competitive market.

Many studies have been conducted to examine the impact of internal knowledge management and talent management strategies in under developing countries (e.g., Chinese manufacturing firms), but few have examined the impact of external knowledge management and talent management strategies. The value of KS has long been recognized by the academic community.

Both the creation and application of organizational knowledge (Hendriks, 2004), which are critical processes in organizational innovation and knowledge management, require knowledge sharing. However, some researchers believe that knowledge sharing is not always beneficial to employee creativity and team performance, and that it can even be harmful in some cases (Cornell \& Stone, 2010; Haas \& Hansen, 2007). Numerous attempts have been made to address the issue of KS quality, including the development and application of knowledge quality measures (Doronin et al., 2020), and KS effectiveness and quality (Raab, Ambos, and Tallman, 2014; Shah et al., 2021). There is still no clear and justifiable measure of the link between knowledge sharing and employee performance.

\subsection{Knowledge Sharing as a Mediator}

Numerous attempts at addressing the issue of KS quality have been made, including the development and application of knowledge quality measures (Darroch \& Mcnaughton, 2002). The style of KS can make a company unique and characteristic, affecting its performance. Moreover, explicit knowledge influences the speed of innovation, while tacit knowledge influences the quality of innovation (Liao et al., 2007). Since the year 2000, there has been an increase in the amount of literature on KS and innovation (Castaneda \& Cuellar, 2019). Cavusgil et al. (2003) found that the more tacit knowledge transferred, the more innovative the firm. This study 
examines the concept of KS and QKS, which is viewed as a complex construct that can have a range of effects on an organization's social, intellectual, and human capital, depending on the information shared and the manner in which it is shared. This investigation employs a previously established methodology, as numerous previous studies have raised similar concerns (Chiu et al., 2006; Cavusgil et al., 2003; Ghobadi, 2015). The purpose of this article is to fill a gap in the literature on the relationship between KS and innovation. Others have stressed the importance of studying innovation and KS together.

The parallel mediation model is used in this investigation (Preacher \& Hayes, 2008). Although in previous studies, scholars have realvead ' $K S$ ' as dependent variable (e.g., Cabrera et al., 2006; Cavaliere, Lombardi, and Giustiniano, 2015), it has also been considered as an independent variable (e.g., Hussain et al., 2018; Safa et al., 2016) or as a mediator influencing creativity and performance (e.g., Ali et al., 2015; Safa \& Von Solms, 2016; Dong \& Yang, 2016; Soto-Acosta \&Cegarra-Navarro, 2016). Consequently, the current study offers a fresh perspective on how KSg can be studied while also emphasizing the dual nature of the phenomenon: knowledge as an input and $\mathrm{KS}$ as a process.

\subsection{Knowledge Sharing Antecedents}

A great deal of work has been done to determine what influences KS and how it is influenced. In light of the fact that high-quality KS is thought to be a key factor in the development of intellectual capital (Muhammad et al., 2018), this study makes use of the Nahapiet and Ghoshal (1998) variables of OFE, VA, and MTE. Tacit knowledge, explicit knowledge, and relationships with other people make up the three types of intellectual assets known as intellectual capital.

OFE. When we speak of OFE, we are referring to the existence of a specific medium for knowledge transfer (Saifi et al., 2016). According to both social presence theory (Bickle et al., 2019) and media richness theory (Daft \& Lengel, 1986), a specific task necessitates the use of a specific type of media channel; this is not necessarily the most advanced or richest, but rather the one that can provide sufficient resources to appropriately transmit and receive information in the most efficient manner (Ali et al., 2017).

VA. The importance of engaging in communication and KS should be recognized by all parties involved in the process. The concept of anticipation of reciprocity, which is relevant to knowledge management theory, has been found to have a strong positive relationship with knowledge sharing behavior (Lai et al., 2014). At the same time, anticipating risks makes it difficult to share information (Ali et al., 2021; Tamjidyamcholo et al., 2014).

MTE. Individual intentions are required in order to carry out high-quality KS activities. When a sharer shares, his or her intentions should be such that he or she can contribute to the team's success, is useful, and wishes to assist others. As a result of his research, Wang (2015) discovered a link between KS intentions and the self-determination theory.

\subsection{Hypothesis Development}

If organizations or firms required their employees to be creative, they need to encourage them and need to provide enviorment that encourages to share their knowledge with each other. This increases organizational capital, which is created when people's knowledge is integrated (Cabrera and Artacho, 2006; Nahapiet and Ghoshal, 1998). One person cannot effectively innovate in a complex process; only by assembling a group of people with diverse backgrounds and skill sets can this be accomplished (Butt et al., 2020; Eisenbeiss, 2008; Zárraga \& Bonache, 2003). It is also important for a team's creativity to be able to communicate its goals to each other (Khan et al., 2021; Pearce \& Ensley, 2004). There is a theory that says that employee creativity isn't always linked to a company's willingness to share its knowledge (Tang, 2019). Employee creativity is a result of an increase in intellectual capital as a result of high-QKS (Leitner, 2015).

In this study, it was proposed that knowledge exchange can improve each of intellectual capital's three components (Wang, 2014). Relationships with strong ties, trusting relationships, and a shared vision necessitate, OFE and combine knowledge before the knowledge resources embedded in those relationships can be fully leveraged (Argote\& Ingram, 2000; Hassan et al., 2019; Nahapiet \& Ghoshal, 1998; Weerakoonet al., 2020). According to Nahapiet \& Ghoshal (1998), the QKS can be positively correlated with the amount of intellectual capital that is created. The five and two quality dimensions adopted from previous studies (Lei et al., 2021; Tsai et al., 2014) that suggested a positive correlation between intellectual capital creation of KS and QKS and respectively. However, only if the quality of employee creativity and intellectual capital creation is taken into account can these two concepts be linked (Ellwart et al., 2015). Based on above-mentioned discussion, following hypotheses are proposed:

H1a: The relationship between opportunity for exhange and employee creativity is mediated by quality of 
knowledge.

H1b: Opportunity for exhange and employee creativity relationship will be mediated by quality of knowledge-sharing.

H2a: Value anticipation and employee creativity relationship will be mediated by quality of knowledge.

$\mathrm{H} 2 \mathrm{~b}$ : Value anticipation and employee creativity relationship will be mediated by quality of knowledge-sharing.

H3a: Motivation to engage and employee creativity relationship will be mediated by quality of knowledge.

H3b: Motivation to engage and employee creativity relationship will be mediated by quality of knowledge-sharing.

\section{Research Method}

\subsection{Parallel Mediation Model}

This study's single-stage parallel mediation model uses only two mediators, but theoretically any number could be used. The relationship between mediators is described as "parallel" because no one mediator affects the other. Only one of the mediators is required for the transition from independent to dependent variables (i.e., the KS and QKS here). Other models with a large number of mediators (Cheung, 2007; Lei et al., 2021) exist, but this study only uses single-step models (Figure 1).

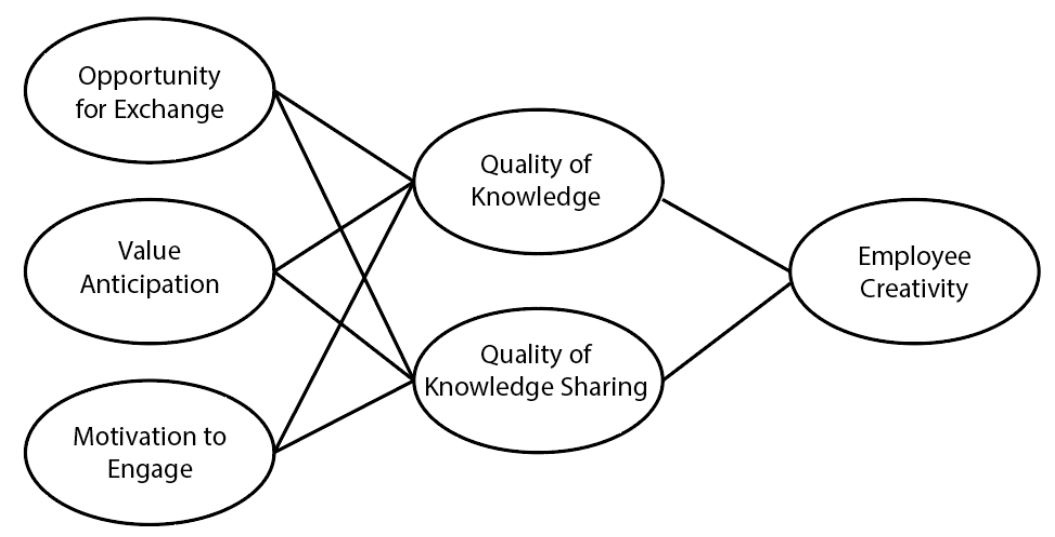

Figure 1. Parallel Mediation Model

\subsection{Analysis Technique}

The relationship between three antecedent variables "OFE, VA and MTE" that have an impact on the creation of intellectual capital is investigated in the current research. More precisely, how these antecedents influence employee creativity is being investigated via the mediating effect of the KS and QKS dimensions. The initial screening tests and exploratory factor analysis (EFA) were carried out using the Statistical Package for Social Science (SPSS) 21 version of the software (IBM). The AMOS 21 version was used to calculate model fit indices and confirmatory factor analysis (CFA) for individual variables and for the entire sample of variables. To proceed with further analysis, it was determined that the results of EFA and reliability check via CFA were satisfactory. Mplus software (version 7) was used to analyze the parallel mediation and whole model hypotheses in order to verify the proposed hypotheses.

\subsection{Survey}

For data collection, an author first discussed the study objectives with the appropriate authorities, and after receiving permission, 450 respondents working in Russian software development firms were randomly selected. A total of 371 people responded to the survey. Both English and Russian were used in the survey, several studies used same aaproach (e.g., Ali et al., 2019). Respondents were asked if there were any phrases or terms that they found difficult or unclear. Following receipt of the questionnaires, no major changes to the text were required. Internal consistency and reliability were checked using Cronbach's alpha. OFE had a Cronbach's alpha of 0.892, VA had a Cronbach's alpha of 0.897, and MTE had a Cronbach's alpha of 0.941. Similarly, mediating variables, KS was $0.919,0.856$ for QKS, and dependent variable (employee creativity) was 0.898 , meet the requirement (Nunnally \& Bernstein, 1994). See Table 1 for more information. 
Table 1. Cronbach's AlphaValues

\begin{tabular}{cc}
\hline Constructs & Cronbach's Alpha \\
\hline OFE & 0.877 \\
VA & 0.829 \\
MTO & 0.901 \\
QK & 0.919 \\
QKS & 0.856 \\
EC & 0.898 \\
\hline
\end{tabular}

Note: "OFE=opportunity for exchange; VA=value anticipation; $M T O=$ motivation to engage; $Q O K=$ quality of knowledge; $Q K S=$ quality of knowledge sharing; $E C=$ employee creativity".

\subsection{Confirmatory Factor Analysis}

The following values were used to assess model fit, in accordance with previous studies (e.g., Barr \& Glynn, 2004; Graves \& Elsass, 2005): the ratio of chi-squared to degrees of freedom ( $\left.\chi^{2 / \mathrm{df}}\right)$, which is less sensitive to sample size than chi-squared alone (Joreskog \& Sorbom, 1996), the root mean square error of approximation (RMSEA), and the Tucker-Le (CFI). For a good fit, $\chi 2 /$ df should be less than 3 , with RMSEA less than 0.06 and TLI and CFI greater than 0.95 (Kline, 1998). (Hu \&Bentler, 1999; Kline, 1998). $\chi 2 / \mathrm{df}$ should be less than 2 (Marsh, Barnes, and Hocevar, 1985), RMSEA should be less than 0.08 (Brown and Cudeck, 1992), and TLI and CFI should be greater than 0.90 to indicate adequate or reasonable fit (Brown and Cudeck, 1992; Marsh, Barnes, and Hocevar, 1985; McDonald \& Ho, 2002). The initial goodness-of-fit for the quality of knowledge indicating that a hierarchical factorial structure adequately represented the data $(\chi 2=458.308(\mathrm{df}=198), \mathrm{CFI}=0.933, \mathrm{TLI}=0.954$, and RMSEA $=0.052,$. The scale's dimensionality was confirmed using the AMOS software.

This study used an additive approach to create a unitary index of knowledge quality by categorizing the entire set of items into five factors and then combining them to form an aggregate measure of kno wledge quality. Table 2 summarizes the results of the confirmatory factor analysis for KS and QKS.

Table 2. Goodness-of-Fit

\begin{tabular}{|c|c|c|c|c|}
\hline & & \multirow{2}{*}{$\overline{\mathrm{KS}}$} & \multirow{2}{*}{\multicolumn{2}{|c|}{ QKS }} \\
\hline & & & & \\
\hline & & \multicolumn{3}{|c|}{ Measurement Model } \\
\hline \multicolumn{5}{|c|}{ Absolute indices } \\
\hline$\chi^{2 / \mathrm{df}}$ & 2.140 & 2.103 & & \\
\hline RMSEA & 0.059 & 0.050 & \multirow[b]{2}{*}{0.006} & \\
\hline p-value & & & & 0.110 \\
\hline \multicolumn{5}{|c|}{ Incremental indices } \\
\hline CFI & 0.910 & 0.990 & & \\
\hline GFI & & 0.878 & \multicolumn{2}{|l|}{0.902} \\
\hline AGFI & & 0.846 & 0.941 & \\
\hline TLI & 0.891 & 0.910 & & \\
\hline PCLOSE & & 0.001 & 0.016 & \\
\hline
\end{tabular}

For QKS, the goodness-of-fit values for the model were $\chi^{2}=16.832, \mathrm{df}=8, \mathrm{p}>0.00, \mathrm{CFI}=0.990, \mathrm{TLI}=0.910$, and RMSEA was 0.050, indicating that a hierarchical factorial structure was an adequate representation of the data. In a similar vein, a higher-order structure explained the two first-order factors of knowledge sharing quality, and a unitary index was calculated based on the explanation. The same method was used to evaluate the level of knowledge. For QK, the goodness-of-fit values for the model are presented in Table 2.

\section{Results}




\subsection{Measurement Model}

The items and constructs' reliability and validity were investigated in the measurement model. Analyzing the measurement model yields the loadings, which give the researcher an idea of the measurement's sturdiness. The measurement model's psychometric properties were evaluated by looking at its reliability, convergent validity, and discriminant validity (Fornell \& Larcker, 1981).

Mean inter-item correlation was applied to verify that all survey-items measures the same constructs because it refers to the mean inter-item correlation (Bryman \& Cramer, 2004; Clark \& Watson, 1995). It can be evaluated using composite reliability and Cronbach's alpha. Item reliability is assessed using Cronbach's alpha; composite reliability is assessed using Cronbach's alpha (Hoque, 2016). As can be seen in Table 4, the Cronbach's alpha values for each of the variables under consideration are quite high.

Table 3. Cronbach's Alpha Values

\begin{tabular}{cc}
\hline Construct & Cronbach's Alpha \\
\hline OFE & 0.912 \\
VA & 0.897 \\
MTE & 0.841 \\
QK & 0.919 \\
QKS & 0.856 \\
EC & 0.898
\end{tabular}

Note:"OFE=opportunity for exchange; $\mathrm{VA}=$ value anticipation; $\mathrm{MTO}=$ motivation to engage; $\mathrm{QOK}=$ quality of knowledge; QKS=quality of knowledge sharing; EC=employee creativity".

\subsection{Path Analysis}

The KS and QKS were examined as mediators between independent variables (OFE, VA, MTE), and dependent variable (employee creativity). The Monte Carlo simulation procedure was used to test the mediation hypothesis. This procedure was used to accurately reflect the asymmetric nature of an indirect effect's sampling distribution (Preacher et al., 2010). Table 4 illustrates the relationship between OFE, VA, MTE, and employee creativity and the KS and QKS.

According to this study, the indirect effects of OFE on QK and QKS on employee creativity were both positive $(0.052 *$ and $0.070 *)$, with 95 percent bias-corrected bootstrap confidence intervals of [0.008-0.058*] and [0.013-0.070*], respectively, when 10,000 Monte Carlo replications were conducted. Additionally, path analyses of VA and MTE on employee creativity as well as path analyses of VA and MTE on employee creativity on the basis of QKS were positive $\left(0.036^{*}, 0.053^{*}, 0.047^{*}, 0.027^{*}\right)$, with 95 percent bias-corrected bootstrap confidence intervals of [0.009-0.054]; [0.006-0.093]; [0.010-0.061] and [0.012-0101], respectively. See Table 4.

Table 4. Path Analysis: Mediating Analysis

\begin{tabular}{llllr}
\hline Path & Indirect Effect & & \\
\hline & Estimate & S.E. & Lower 2.5\% & Upper 2.5\% \\
$\mathrm{OFE} \rightarrow \mathrm{QK} \rightarrow$ EC & $0.052^{*}$ & 0.025 & 0.008 & 0.058 \\
$\mathrm{VA} \rightarrow \mathrm{QK} \rightarrow$ EC & $0.036^{*}$ & 0.022 & 0.009 & 0.054 \\
$\mathrm{MTE} \rightarrow \mathrm{QK} \rightarrow$ EC & $0.047^{*}$ & 0.023 & 0.010 & 0.061 \\
$\mathrm{VA} \rightarrow \mathrm{QKS} \rightarrow$ EC & $0.053^{*}$ & 0.030 & 0.006 & 0.093 \\
$\mathrm{OFE} \rightarrow \mathrm{QKS} \rightarrow$ EC & $0.070^{*}$ & 0.035 & 0.013 & 0.070 \\
$\mathrm{MTE} \rightarrow$ QKS $\rightarrow$ EC & $0.027^{*}$ & 0.033 & 0.012 & 0.101 \\
\hline
\end{tabular}

Note: ${ }^{*} \mathrm{p}<0.05$; "OFE=opportunity for exchange; $\mathrm{VA}=$ value anticipation; MTE=motivation to engage; $\mathrm{QK}=$ quality of knowledge; $\mathrm{QKS}=$ quality of knowledge sharing".

In the study, the findings revealed that OFE, VA, and MTE were all positively and significantly related to employee creativity, both in terms of KS and QKS, respectively. 


\section{Discussion}

\subsection{Theoretical Contribution}

The results showed unequivocally that employee creativity is influenced by the quality dimensions of KS. While some studies have found a negative link between employee and organizational performance and KS (Liu et al., 2011; Tang, 2019), others have found a positive one. Regardless of the discrepancy in findings, no one knows for sure how to measure KS. There are a variety of ways to measure how effective KS is from a quantitative perspective, such as the number of reports or responses, or the number of feedbacks (Hau et al., 2016). However, the actual study focused on the quality of the information shared.

According to Nonaka (1998), there are four steps or processes that lead to the creation of new knowledge. Here, we can compare the quality of codification and KS by comparing them to the quality of externalization. These processes are supposed to lead to greater intellectual capital creation and subsequent creativity by employees, in theory, if they are executed well. KS in future research must be understood in terms of what knowledge is shared (quantity, impartiality, verifiability and relevance), as well as how it is shared (comprehensibility and timeliness).

Employee innovation is examined in this study, which focuses on the dual nature of KS, manifested in the form of parallel mediation. Future studies can be guided by the study's findings, which quantify the KS and QKS. Furthermore, it emphasizes the significance of both the content and the dissemination of knowledge in fostering inventiveness. These quality dimensions of KS are used in the current study to assess the relationship between employee creativity and the previously identified antecedents of intellectual capital creation. So the research shows that there is a link between the theory of social capital and employee innovation.

\subsection{Practical Contribution}

Knowledge management literature will insight greatly from this study's findings. According to the results of the current study, KS has a greater effect on employee creativity when knowledge is shared in a high-quality environment. As a result, rather than attempting to replicate teamwork and KS through policies and procedures, organizations should look for ways to improve the QKS. Social capital theory is taken into account in this study as the driving force behind the creation of intellectual capital and the creativity of employees.

Knowledge-intensive organizations and firms should exercise caution when implementing KS initiatives that are solely focused on quantitative outcomes, such as the number of reports produced or the number of feedback messages sent, according to the findings of the research. This policy, which encourages sharing for the sake of sharing, may have no effect on the performance of an employee or the performance of the company. As an alternative, the study emphasizes the fact that high-quality KS, rather than large amounts of it, produces the greatest number of benefits.

When it comes to innovation and business performance, knowledge management has emerged as one of the most important disciplines for modern organizations to keep in mind. Knowledge-intensive organizations, such as universities, information technology, banks, and other financial institutions, can benefit from the study's findings, which provide a deeper look at KS processes.

\subsection{Limitations and Future Research}

This study has several limitations. First, in this study author targetd the respondents were based in Russia, which has a number of implications for both geography and culture. The information technology industry, in particular, is regarded as a knowledge-intensive and relatively new field. There is a significant limitation in the study's findings because of the problem of representativeness. This means that further study could be done in other regions and industries. The development, testing, and refinement of sound instruments in the KM literature continues to be a work in progress. Additional studies are needed to confirm the external validity of our results despite the fact that the dataset's reliability and validity have been empirically tested. In the third point, it would be interesting to examine the construct using a multi-level approach and to include some objective measures because the study relied on subjective Likert scale responses from team members. The proposed quality-based construct can be used to test other antecedents of knowledge sharing.

\subsection{Conclusion}

All hypotheses were supported, indicating that quality dimensions of KS are important for increasing employee creativity and productivity. The researchers also discovered that Nahapiet and Ghosal's (1998) four conditions for creating intellectual capital were positively related to all of the study's quality dimensions of KS.The last decade has seen a surge in interest in KS. This study examines the QKS and added academics a high-quality 
perspective on KS. Using previously untapped theoretical perspectives, this paper examined how KS can influence employee creativity. These three elements are critical to the process of combining KS and QKS.

\section{References}

Adams, M., Day, G., \& Dougherty, D. (1998). Enhancing new product development performance: An organizational learning perspective. The Journal of Product Innovation Management, 15(5), 403-422. https://doi.org/10.1111/1540-5885.1550403

Aggarwal, I., \& Woolley, A. W. (2019). Team creativity, cognition, and cognitive style diversity. Management Science, 65(4), 1586-1599. https://doi.org/10.1287/mnsc.2017.3001

Ali, M., Lei, S., Rehman, A. R., \& Anjum, A., (2015). Relationship of strategic human resource management practices with organization performance and employee relation climate. Journal of Basic and Applied Scientific Research, 5(2), 39-50.

Ali, M., Lei, S., Freeman, S., \& Khan, M. M. (2019). Implemented and perceived high-performance work system and its effect on branch performance: A 2-1-2 mediational multilevel approach. Employee Relations, 41(4), 793-810. https://doi.org/10.1108/ER-08-2017-0186

Ali, M., Khan, A., Khan, M., Butt, A. S., \& Shah, H. (2021). Mindfulness and study engagement: mediating role of psychological capital and intrinsic motivation. Journal of Professional Capital and Community. https://doi.org/10.1108/JPCC-02-2021-0013

Argote, L., \& Ingram, P. (2000). Knowledge transfer: A basis for competitive advantage in firms. Organizational behavior and human decision processes, 82(1), 150-169. https://doi.org/10.1006/obhd.2000.2893

Ahmad, F., \& Karim, M. (2019). Impacts of knowledge sharing: a review and directions for future research. Journal of Workplace Learning, 31(3), 207-230. https://doi.org/10.1108/JWL-07-2018-0096

Al-Kurdi, O., El-Haddadeh, R., \& Eldabi, T. (2018). Knowledge sharing in higher education institutions: A systematic review. Journal of Enterprise Information Management, 31(2), 226-246. https://doi.org/10.1108/JEIM-09-2017-0129

Barr, P. S., \& Glynn, M. A. (2004). Cultural variations in strategic issue interpretation: Relating cultural uncertainty avoidance to controllability in discriminating threat and opportunity. Strategic Management Journal, 25(1), 59-67. https://doi.org/10.1002/smj.361

Bayraktaroglu, A. E., Calisir, F., \& Baskak, M. (2019). Intellectual capital and firm performance: an extended VAIC model. Journal of Intellectual Capital, 20(3), 406-425. https://doi.org/10.1108/JIC-12-2017-0184

Bickle, J. T., Hirudayaraj, M., \& Doyle, A. (2019). Social presence theory: Relevance for HRD/VHRD research and practice. Advances in Developing Human Resources, 21(3), 383-399. https://doi.org/10.1177/1523422319851477

Browne, M. W., \& Cudeck, R. (1992). Alternative ways of assessing model fit. Sociological Methods \& Research, 21(2), 230-258. https://doi.org/10.1177/0049124192021002005

Bryman, A., \& Cramer, D. (2004). Quantitative data analysis with SPSS 12 and 13: A guide for social scientists. Routledge. https://doi.org/10.4324/9780203498187

Butt, A. S., Shah, S. H., Noor, S., \& Ali, M. (2020). Knowledge hiding in a buyer-supplier relationship: Present and future scope. International Journal of Knowledge Management, 16(2), 18-29. https://doi.org/10.4018/IJKM.2020040102

Cabrera, C., Artacho, R., \&Giménez, R. (2006). Beneficial effects of green tea: A review. Journal of the American College of Nutrition, 25(2), 79-99. https://doi.org/10.1080/07315724.2006.10719518

Cameron Cockrell, R., \& Stone, D. N. (2010). Industry culture influences pseudo-knowledge sharing: A multiple mediation analysis. Journal of Knowledge Management, 14(6), 841-857. https://doi.org/10.1108/13673271011084899

Cardinal, L., Allesandri, T., \& Turner, S. (2001). Knowledge codifiability, resources, and science based innovation. Journal of Knowledge Management, 5(2), 142-154. https://doi.org/10.1108/13673270110393266

Castaneda, D. I., \& Cuellar, S. (2019). Knowledge sharing and innovation: A systematic review. Knowledge and Process Management, 27(3), 1-15. https://doi.org/10.1002/kpm.1637

Cavaliere, V., Lombardi, S., \& Giustiniano, L. (2015). Knowledge sharing in knowledge-intensive manufacturing firms. An empirical study of its enablers. Journal of Knowledge Management, 19(6), 1124-1145. 
https://doi.org/10.1108/JKM-12-2014-0538

Cavusgil, S., Calantone, R., \& Zhao, Y. (2003). Tacit knowledge transfer and firm innovation capability. Journal of Business \& Industrial Marketing, 18(1), 6-21. https://doi.org/10.1108/08858620310458615

Clark, L. A., \& Watson, D. (1995). Constructing validity: Basic issues in objective scale development. Psychological Assessment, 7(3), 309. https://doi.org/10.1037/1040-3590.7.3.309

Daft, R. L., \& Lengel, R. H. (1986). Organizational information requirements, media richness and structural design. Management Science, 32(5), 554-571. https://doi.org/10.1287/mnsc.32.5.554

Darroch, J., \& McNaughton, R. (2002). Examining the link between knowledge management practices and types of innovation. Journal of Intellectual Capital, 3(3), 210-222. https://doi.org/10.1108/14691930210435570

DeLone, W. H., \& McLean, E. R. (2003). The DeLone and McLean model of information systems success: a ten-year update. Journal of Management Information Systems, 19(4), 9-30. https://doi.org/10.1080/07421222.2003.11045748

Dong, J. Q., \& Yang, C. H. (2016). Being central is a double-edged sword: Knowledge network centrality and new product development in US pharmaceutical industry. Technological Forecasting and Social Change, 113, 379-385. https://doi.org/10.1016/j.techfore.2016.07.011

Dong, Y., Bartol, K. M., Zhang, Z. X., \& Li, C. (2017). Enhancing employee creativity via individual skill development and team knowledge sharing: Influences of dual-focused transformational leadership. Journal of Organizational Behavior, 38(3), 439-458. https://doi.org/10.1002/job.2134

Doronin, D., Shen, L., \& Ali, M. (2020). Parallel mediating effect of knowledge sharing quality on team innovativeness. Technology Analysis \& Strategic Management, 32(12), 1449-1461. https://doi.org/10.1080/09537325.2020.1775805

Diercks, G., Larsen, H., \& Steward, F. (2019). Transformative innovation policy: Addressing variety in an emerging policy paradigm. Research Policy, 4(2), 880-894. https://doi.org/10.1016/j.respol.2018.10.028

Eisenbeiss, S. A., Van Knippenberg, D., \& Boerner, S. (2008). Transformational leadership and team innovation: integrating team climate principles. Journal of applied psychology, 93(6), 1438. https://doi.org/10.1037/a0012716

Ellwart, T., Happ, C., Gurtner, A., \& Rack, O. (2015). Managing information overload in virtual teams: Effects of a structured online team adaptation on cognition and performance. European Journal of Work and Organizational Psychology, 24(5), 812-826. https://doi.org/10.1080/1359432X.2014.1000873

Fauzi, M. A. (2019). Knowledge sharing in Asia Pacific via virtual community platform: a systematic review. International Journal of Web Based Communities, 15(4), 368-394. https://doi.org/10.1504/IJWBC.2019.103186

Ferreira, J., Mueller, J., \& Papa, A. (2018). Strategic knowledge management: theory, practice and future challenges. Journal of Knowledge Management, 24(2), 121-126. https://doi.org/10.1108/JKM-07-2018-0461

Fornell, C., \& Larcker, D. F. (1981). Evaluating structural equation models with unobservable variables and measurement error. Journal of Marketing Research, 18(1), 39-50. https://doi.org/10.1177/002224378101800104

Gang, K., \& Ravichandran, T. (2014). Exploring the determinants of knowledge exchange in virtual communities. IEEE Transactions on Engineering Management, 62(1), 89-99. https://doi.org/10.1109/TEM.2014.2376521

Ghobadi, S. (2015). What drives knowledge sharing in software development teams: A literature review and classification framework. Information \& Management, 52(1), 82-97. https://doi.org/10.1016/j.im.2014.10.008

Graves, L. M., \& Elsass, P. M. (2005). Sex and sex dissimilarity effects in ongoing teams: Some surprising findings. Human Relations, 58(2), 191-221. https://doi.org/10.1177/0018726705052181

Haas, M. R., \& Hansen, M. T. (2007). Different knowledge, different benefits: Toward a productivity perspective on knowledge sharing in organizations. Strategic Management Journal, 28(11), 1133-1153. https://doi.org/10.1002/smj.631

Hassan, S. S. H., Ali, M. Doronin, D., \& Hussain, S. T. (2019). Prosumption: bibliometric analysis using HistCite and VOSviewer. Kybernetes, 49(3), 1020-1045.

Hau, Y. S., \& Kang, M. (2016). Extending lead user theory to users' innovation-related knowledge sharing in the 
online user community: the mediating roles of social capital and perceived behavioral control. International Journal of Information Management, 36(4), 520-530. https://doi.org/10.1016/j.ijinfomgt.2016.02.008

Hendriks, P. (2004). Assessing the role of culture in knowledge sharing, in proceedings of fifth European conference in organization, knowledge, learning and capabilities. Austria: Innsbruck.

Hinkin, T. R. (1995). A review of scale development practices in the study of organizations. Journal of Management, 21(5), 967-988. https://doi.org/10.1177/014920639502100509

Hoque, M. R. (2016). An empirical study of mHealth adoption in a developing country: The moderating effect of gender concern. BMC Medical Informatics and Decision Making, 16(1), 51. https://doi.org/10.1186/s12911-016-0289-0

Hsu, M. H., Chang, C. M., \& Yen, C. H. (2011). Exploring the antecedents of trust in virtual communities. Behaviour \& Information Technology, 3(5), 587-601. https://doi.org/10.1080/0144929X.2010.549513

Hu, L. T., \& Bentler, P. M. (1999). Cutoff criteria for fit indexes in covariance structure analysis: Conventional criteria versus new alternatives. Structural Equation Modeling: A Multidisciplinary Journal, 6(1), 1-55. https://doi.org/10.1080/10705519909540118

Hussain, S. T., Lei, S., Akram, T, Syed, J., Syed, H. H., \& Muhammad, A. (2018). Kurt Lewin's change model: A critical review of the role of leadership and employee involvement in organizational change. Journal of Innovation and Knowledge, 3(1), 44-55. https://doi.org/10.1016/j.jik.2016.07.002

Kane, G. C. (2017). The evolutionary implications of social media for organizational knowledge management. Information and organization, 27(1), 37-46. https://doi.org/10.1016/j.infoandorg.2017.01.001

Khan, N. A., Khan, N. A., Bahadur, W., \& Ali, M. (2021). Mobilepayment adoption: A multi-theory model, multi-method approach and multi-country study. International Journal of Mobile Communications, 19(4), 467-491. https://doi.org/10.1504/IJMC.2021.116119

Kianto, A., Sáenz, J., \& Aramburu, N. (2017). Knowledge-based human resource management practices, intellectual capital and innovation. Journal of Business Research, 81(1), 11-20. https://doi.org/10.1016/j.jbusres.2017.07.018

Kline, R. B. (1998). Software review: Software programs for structural equation modeling: Amos, EQS, and LISREL. Journal of Psycho Educational Assessment, 16(4), 343-364. https://doi.org/10.1177/073428299801600407

Kremer, H., Villamor, I., \& Aguinis, H. (2019). Innovation leadership: Bestpractice recommendations for promoting employee creativity, voice and knowledge sharing. Business Horizons, 62(1), 65-74. https://doi.org/10.1016/j.bushor.2018.08.010

Lai, H. M., \& Chen, T. T. (2014). Knowledge sharing in interest online communities: A comparison of posters and lurkers. Computers in Human Behavior, 35(3), 295-306. https://doi.org/10.1016/j.chb.2014.02.004

Lei, S., Sun, C., \& Ali, M. (2021). Influencing factors and paths of upgrading consumer goods industry in Shanghai: a FsQCA approach. International Journal of Emerging Markets (ahead-of-print).

Lei, S., Qin, C., \& Ali, M. (2021). The impact of authentic leadership on individual and team creativity: a multilevel perspective. Leadership and Organization Development Journal, 42(4), 644-662. https://doi.org/10.1108/LODJ-12-2019-0519

Leitner, K. H. (2015). Intellectual capital, innovation, and performance: Empirical evidence from SMEs. International Journal of Innovation Management, 19(5), 1550-1566. https://doi.org/10.1142/S1363919615500607

Liao, S. H., Fei, W. C., \& Chen, C. C. (2007). Knowledge sharing, absorptive capacity, and innovation capability: An empirical study of Taiwan's knowledge-intensive industries. Journal of Information Science, 33(3), 340-359. https://doi.org/10.1177/0165551506070739

Liao, T. H. (2017). Developing an antecedent model of knowledge sharing intention in virtual communities. Universal Access in the Information Society, 16(1), 215-224. https://doi.org/10.1007/s10209-016-0452-5

Liu, Y., \& Phillips, J. S. (2011). Examining the antecedents of knowledge sharing in facilitating team innovativeness from a multilevel perspective. International Journal of Information Management, 31(1), 44-52. https://doi.org/10.1016/j.ijinfomgt.2010.05.002

Madhavan, R., \& Grover, R. (1998). From embedded knowledge to embodied knowledge: New product 
development as knowledge management. Journal of Marketing, 62(4), 1-12. https://doi.org/10.1177/002224299806200401

Marsh, H. W., Barnes, J., \& Hocevar, D. (1985). Self-other agreement on multidimensional self-concept ratings: Factor analysis and multitrait-multimethod analysis. Journal of Personality and Social Psychology, 49(5), 1360. https://doi.org/10.1037/0022-3514.49.5.1360

McDonald, R. P., \& Ho, M. H. R. (2002). Principles and practice in reporting structural equation analyses. Psychological Methods, 7(1), 64. https://doi.org/10.1037/1082-989X.7.1.64

Muhammad, A., Lei, S., Syed, A. A., \& Syed, T. H. (2017). Relationship of external knowledge management and performance of Chinese manufacturing firms: The mediating role of talent management. International Business Research, 10(8). https://doi.org/10.5539/ibr.v10n6p248

Muhammad, A., Lei, S., Jie Z. S., \& Anisur, R. (2018). Empowering leadership and employee performance: A mediating role of thriving at work. International Journal of Asian Business and Information Management, 9(2), 1-14. https://doi.org/10.4018/IJABIM.2018040101

Muhammad, A., Lei, S., \& Wei, Y. (2018). The mediating role of the employee relations climate in the relationship between strategic HRM and organizational performance in Chinese banks. Journal of Innovation \& Knowledge, 3(3), 115-122. https://doi.org/10.1016/j.jik.2016.12.003

Muhammad, A., Yan, J., \& Khan, M. R. (2020). Mindfulness and study engagement: mediating role of psychological capital and intrinsic motivation. Academy of Management Proceedings. https://doi.org/10.5465/AMBPP.2020.14737abstract

Nahapiet, J., \& Ghoshal, S. (1998). Social capital, intellectual capital, and the organizational advantage. Academy of Management Review, 23(2), 242-266. https://doi.org/10.5465/amr.1998.533225

Nonaka, I., \& Nishihara, A. H. (2018). Introduction to the concepts and frameworks of knowledge-creating theory. Knowledge Creation in Community Development (1-15). Palgrave Macmillan, Cham. https://doi.org/10.1007/978-3-319-57481-3_1

Nunnally, J. C., \& Bernstein, I. H. (1994). Validity. Psychometric Theory, 3, 99-132.

Park, S., \& Kim, E. J. (2018). Fostering organizational learning through leadership and knowledge sharing. Journal of Knowledge Management, 22(6), 1408-1423. https://doi.org/10.1108/JKM-10-2017-0467

Pearce, C. L. (2004). The future of leadership: Combining vertical and shared leadership to transform knowledge work. Academy of Management Perspectives, 18(1), 47-57. https://doi.org/10.5465/ame.2004.12690298

Preacher, K. J., \& Hayes, A. F. (2008). Asymptotic and resampling strategies for assessing and comparing indirect effects in multiple mediator models. Behavior Research Methods, 40(3), 879-891. https://doi.org/10.3758/BRM.40.3.879

Preacher, K. J., Zyphur, M. J., \& Zhang, Z. (2010). A general multilevel SEM framework for assessing multilevel mediation. Psychological methods, 15(3), 209. https://doi.org/10.1037/a0020141

Raab, K. J., Ambos, B., \& Tallman, S. (2014). Strong or invisible hands? Managerial involvement in the knowledge sharing process of globally dispersed knowledge groups. Journal of World Business, 49(1), 32-41. https://doi.org/10.1016/j.jwb.2013.02.005

Razaka, N. A., Pangilb, F., Zinb, Md. L., Yunusc, N. A. M., \& Asnawic, N. H. (2016). Theories of knowledge sharing behavior in business strategy. Procedia Economics and Finance, 37(2016), 545-553. https://doi.org/10.1016/S2212-5671(16)30163-0

Ruiz-Jiménez, J. M., del Mar Fuentes-Fuentes, M., \& Ruiz-Arroyo, M. (2016). Knowledge combination capability and innovation: The effects of gender diversity on top management teams in technology-based firms. Journal of Business Ethics, 135(3), 503-515. https://doi.org/10.1007/s10551-014-2462-7

Rusly, F. H., Corner, J. L., \& Sun, P., (2012). Positioning change readiness in knowledge management research. Journal of Knowledge Management, 16(2), 329-355. https://doi.org/10.1108/13673271211218906

Safa, N. S., \& Von Solms, R. (2016). An information security knowledge sharing model in organizations. Computers in Human Behavior, 57, 442-451. https://doi.org/10.1016/j.chb.2015.12.037

Saifi, S. A., Dillon, S., \& McQueen, R. (2016). The relationship between face to face social networks and knowledge sharing: an exploratory study of manufacturing firms. Journal of knowledge management, 20(2), 308-326. https://doi.org/10.1108/JKM-07-2015-0251 
Shen, L., Sun, C., \& Ali, M. (2021a). Role of servitization, digitalization, and innovation performance in manufacturing enterprises. Sustainability, 13(17), 1-17. https://doi.org/10.3390/su13179878

Shen, L., Sun, C., \& Ali, M. (2021b). Path of smart servitization and transformation in the textile industry: A case study of various regions in China. Sustainability, 13(21), 1-16. https://doi.org/10.3390/su132111680

Shah, S. H., Noor, S, Lei, S., \& Ali, M. (2021). Role of privacy/safety risk and trust on the development of prosumption and value co-creation under the sharing economy: A Moderated mediation model. Information Technology for Development, 27(4), 718-735. https://doi.org/10.1080/02681102.2021.1877604

Shan, S., Xin, T., Wang, L., Li, Y., \& Li, L. (2013). Identifying influential factors of knowledge sharing in emergency events: a virtual community perspective. Systems Research and Behavioral Science, 30(3), 367-382. https://doi.org/10.1002/sres.2181

Soto-Acosta, P., \& Cegarra-Navarro, J. G. (2016). New ICTs for knowledge management in organizations. Journal of Knowledge Management, 20(3), 417-422. https://doi.org/10.1108/JKM-02-2016-0057

Subramaniam, M., \& Venkatraman, N. (2001). Determinants of transnational new product development capability: Testing the influence of transferring and deploying tacit overseas knowledge. Strategic Management Journal, 22(4), 359-378. https://doi.org/10.1002/smj.163

Syed, A. A., Haider, J., Ali, M., Ali, S. I., \& Ming, X. (2017). Emerging tourism between Pakistan and China: Tourism opportunities via China-Pakistan economic corridor. International Business Research, 10(8). https://doi.org/10.5539/ibr.v10n8p204

Tamjidyamcholo, A., Baba, M. S. B., Shuib, N. L. M., \& Rohani, V. A. (2014). Evaluation model for knowledge sharing in information security professional virtual community. Computers \& Security, 43, 19-34. https://doi.org/10.1016/j.cose.2014.02.010

Tang, Y. E., \& Marinova, D. (2019). When less is more: the downside of customer knowledge sharing in new product development teams. Journal of the Academy of Marketing Science, 1-20. https://doi.org/10.1007/s11747-019-00646-w

Tsai, K. H., \& Hsu, T. T. (2014). Cross-Functional collaboration, competitive intensity, knowledge integration mechanisms, and new product performance: A mediated moderation model. Industrial Marketing Management, 43(2), 293-303. https://doi.org/10.1016/j.indmarman.2013.08.012

Van de Ven, A. H. (1986). Central problems in the management of innovation. Management Science, 32(5), 590-607. https://doi.org/10.1287/mnsc.32.5.590

Wang, Z., Wang, N., \& Liang, H. (2014). Knowledge sharing, intellectual capital and firm performance. Management decision, 52(2), 230-258. https://doi.org/10.1108/MD-02-2013-0064

Wang, W. T., \& Hou, Y. P. (2015). Motivations of employees' knowledge sharing behaviors: A self-determination perspective. Information and Organization, 25(1), 1-26. https://doi.org/10.1016/j.infoandorg.2014.11.001

Wasko, M. M., \& Faraj, S. (2005). Why should I share? Examining social capital and knowledge contribution in electronic networks of practice. MIS quarterly, 29(1), 35-57. https://doi.org/10.2307/25148667

Weerakoon, C., McMurray, A. J., Rametse, N., \& Arenius, P. (2020). Knowledge creation theory of entrepreneurial orientation in social enterprises. Journal of Small Business Management, 58(4), 834-870. https://doi.org/10.1080/00472778.2019.1672709

Yan, J, Ali, M., Khan, M. M., Syed, H., \& Butt, A. S. (2021). The effect of promotion regulatory focus on service performance. The Service Industries Journal. https://doi.org/10.1080/02642069.2021.2003340

Zárraga, C., \& Bonache, J. (2003). Assessing the team environment for knowledge sharing: An empirical analysis. International Journal of Human Resource Management, 14(7), 1227-1245. https://doi.org/10.1080/0958519032000114282

\section{Copyrights}

Copyright for this article is retained by the author(s), with first publication rights granted to the journal.

This is an open-access article distributed under the terms and conditions of the Creative Commons Attribution license (http://creativecommons.org/licenses/by/4.0/). 